Agrosearch (2007) 9 No 1\&2: 17 - 22

\title{
THE FEEDING VALUE OF HATCHERY WASTE MEAL IN THE DIETS OF EARLY-WEANED PIGLETS.
}

\author{
Adeniji, A.A. and Adesiyan, S.S. \\ Department of Animal Science,University of Abuja, Abuja, Nigeria.
}

\begin{abstract}
In an experiment designed to investigate the feeding value of hatchery waste meal (HWM) in the diets of early-weaned piglets, HWM was included in the experimental diets at 0 , $7.5,15,22.5$, and $30 \%$. Thirty piglets weaned at 3 weeks were used for the experiment, which lasted for a period of 8 weeks in a complete randomized design. The results showed that pigs fed with the various treatments had comparable $(P>0.05)$ feed to gain ratio. However, there was a gradual decrease in weight gain, nitrogen intake and nitrogen digestibility as the levels of $H W M$ in the diets increased. The feed intake, weight gain, nitrogen intake and digestibility of the piglets fed on the control diet was significantly higher $(P<0.05)$ than those fed on the other levels of the HWM. The feed cost analysis revealed a gradual decrease in feed cost as the levels of the HWM increased in the diets. The early-weaned piglets can tolerate up to $22.5 \%$ HWM in their diets.
\end{abstract}

Keywords: Early-weaned piglets, hatchery waste meal, feeding value, digestibility.

\section{Introduction}

The high cost and unavailability of the conventional feed ingredients have led to the search for alternative (unconventional) sources of protein and energy for livestock production. The use of animal wastes or by-products has a considerable significance in the diets of livestock (Sonaiya, 1987). Hatchery waste meal (HWM) is a hatchery by-product, a waste generated from poultry industry, which consist of shells of hatched eggs, unhatched eggs, dead chicks, unsaleable chicks and the embryonic fluids. It is an animal protein supplement that is readily available in the hatcheries; but currently a waste constituting disposal problem.

HWM is high in crude protein and contains substantial amount of energy with values of $23.75 \%$ and $4.88 \mathrm{Mcal} / \mathrm{kg}$ respectively (Vanderpopuliere et al $_{2}$ 1976; Belewu, 1986). A critical look at its amino acid profile indicated that the protein quality compares favourably with other animal protein sources (Belewu, 1996).

This study was aimed at establishing the optimum inclusion level of HWM in the diets of early-weaned piglets and the effect of such on the cost of feeding, growth and digestibility performance of the experimental piglets.

\section{Materials and Methods}

The hatchery waste which is the waste from the incubation of fertile eggs was collected on the hatched-day and processed by boiling in a covered steel drum at about $100^{\circ} \mathrm{C}$ for two hours in order to sterilize the waste. It was then sun-dried for about three days until the moisture level was reduced to about $9 \%$.

Thirty piglets weaned at 3 weeks of age were divided into 5 treatment groups (Table 1). HWM was included in the diets of the piglets at 0,7.5, 15, 22.5 and $30 \%$. Each group of 6 piglets was assigned to an experimental diet for a period of 8 weeks such that there were 3 replicates per treatment and 2 pigletsper replicate. Digestibility trial was conducted during the last week of the 
experiment in which the animals were kept inside metabolic cages for ease of urine and faecal collection. The total feacal collection method was adopted in which feacal samples were collected over 72 hours. Collected feaces were ovendried at $70^{\circ} \mathrm{C}$ for $24 \mathrm{hrs}$ and stored, while the urine was collected in plastic bottles containing concentrated hydrochloric acid (HCL) as preservative.

All proximate analyses were determined using the methods of A.O.A.C., (1985). The metabolizable energy of the HWM and the diets were calculated by using the formula given by Carpenter and Clegg (1956). Records of initial and weekly live weight and daily feed intake were kept; and the feed-to-gain ratio, feed cost and feed cost per weight gain calculated. All data were subjected to analysis of variance using the completely randomized design (Steel and Torrie, 1980) and where significant, treatment means were compared by the Duncan's multiple range test. (Duncan, 1955)

\section{Results}

The HWM fed had $91.00 \%$ dry matter, $22.09 \%$ crude protein, $6.17 \%$ ether extract, $0.70 \%$ crude fibre, $32.00 \%$ ash, and $30.64 \%$ nitrogen free extract. The growth performance characteristics of early-weaned piglets fed on different inclusion levels of HWM are presented in Table 2. There was a decrease in feed intake as the levels of HWM in the diets increased. The piglets fed on the control diet had higher $(\mathrm{P}<0.05)$ feed intake value of $0.57 \mathrm{~kg}$ while those fed on the HWM diets had comparable $(\mathrm{P}>0.05)$ feed intake values. There was a significant difference in the final body weights of the piglets fed on the graded levels of HWM. The piglet fed on the control diet had a higher $(\mathrm{P}<0.05)$ final body weight value $(18.46 \mathrm{Kg})$ than those fed on the HWM based diets. The piglets fed on 7.5\% HWM had a comparable $(\mathrm{P}>0.05)$ final weight of $9.79 \mathrm{~kg}$ with those fed on $15 \% \mathrm{HWM}$ diet $(7.77 \mathrm{Kg})$. The piglets fed 22.5 and $30 \%$ diets also had comparable $(\mathrm{P}>0.05)$ final body weight values of 6.09 and $4.97 \mathrm{~kg}$ respectively. Piglets fed on the control diets had a significantly higher $(\mathrm{P}<0.05)$ body weight gain $(0.26 \mathrm{Kg})$ than those fed on the HWM diets. The body weight gain of the pigs fed HWM diets decreased as the levels of HWM in the diets increased. Piglets fed on 7.5\% HWM diet had higher $(\mathrm{P}<0.05)$ weight gain of $0.11 \mathrm{~kg}$; which is lower $(\mathrm{P}<0.05)$ than those fed on the control diet. Piglets on 15 and $22.5 \%$ HWM had comparable ( $\mathrm{P}>0.05)$ body weight gain $(0.07$ and $0.04 \mathrm{~kg}$ respectively). Those fed on $30 \%$ HWM diet that had the lowest weight gain value of $0.02 \mathrm{~kg}$ was comparable $(\mathrm{P}>0.05)$ to the weight gain value obtained for the piglets fed on $22.5 \% \mathrm{HWM}$ diet.

The results showed no significant effect of treatment on the feed- to -gain ratio of the piglets fed the graded levels of HWM diets. Piglets fed on the control diet had the best value of 2.19 and the performance tended to decrease as the level of HWM increased in the diets.

Feed cost seemed to be decreasing as the inclusion level of HWM increased in the diets. The cost of feed varied from N43.87 in the control feed to N32.88 in the $30 \% \mathrm{HWM}$ included feed. Feed cost per weight gain seemed to be increasing as the level of HWM increased in the diet of the piglets, except for the $22.5 \% \mathrm{HWM}$ fed piglets.

The effects of the inclusion of HWM in the diets of early-weaned piglets on nitrogen digestibility of the fed piglets are shown on Table 3 . There was significant decrease $(\mathrm{P}<0.05)$ in nitrogen intake as the dietary levels of HWM increased. Piglets fed on the control and $7.5 \%$ HWM had nitrogen intake values of 18.20 and $16.20 \mathrm{~g}$ respectively.

Those fed on 22.5 and $30 \%$ HWM had low $(\mathrm{P}<0.05)$ nitrogen intake values of 4.55 and $6.21 \mathrm{~g}$ respectively. There were also significant differences in urinary nitrogen values of the 
piglets fed on graded dietary levels of HWM. Piglets fed on the control and 7.5\% HWM however had comparable $(\mathrm{P}>0.05)$ urinary nitrogen values of $0.29 \mathrm{~g}$ each. Those fed on 22.5 and $30 \%$ HWM also had comparable $(\mathrm{P}>0.05)$ values of 0.13 and $0.16 \mathrm{~g}$ respectively which were lower $(\mathrm{P}<0.05)$ than $0.24 \mathrm{~g}$ obtained for the $15 \% \mathrm{HWM}$ fed piglets. The statistical analysis of the faecal nitrogen also showed a significant difference among the piglets fed various levels of HWM diets. The piglets fed 7.5\% HWM had higher $(\mathrm{P}<0.05)$ faecal nitrogen value $(3.41 \mathrm{~g})$ than those fed on other HWM diets. However, there was an insignificant difference in the total nitrogen output values of the piglets fed on different levels of HWM diet. The values of nitrogen retained decreased $(\mathrm{P}<0.05)$ as the levels of HWM increased in the diets. The piglets fed on the control diets had the highest $(\mathrm{P}<0.05)$ nitrogen digestibility value of $82.53 \%$, which was significantly higher than for those piglets fed on the HWM diets. The nitrogen digestibility decreased $(\mathrm{P}<0.05)$ as the levels of HWM increased in the diets. The piglets on the $22.5 \% \mathrm{HWM}$ diet had the lowest $(\mathrm{P}<0.05)$ nitrogen digestibility value.

\section{Discussion}

The average feed intake that was reported to have decreased with the increase in the levels of HWM in the diets might have been due to the unpleasant odour of the HWM since pigs are macrosomates; they have well developed olfactory organ. Olatidoye (2003) made a similar observation where feed intake decreased in grower pigs fed HWM. Probably with the use of flavourants to mask this repulsive odour, acceptability of this feedstuff might be improved, particularly with pigs being sensitive to odour or smell.

The significant difference in the final weight of the piglets fed on graded levels of dietary HWM was obviously due to the feed intake values. Generally, animals gain more weight when they take more feed (Church, 1973). The same could be said of body weight gain values, which decreased as the inclusion levels of the HWM increased in the diets, following the same pattern as the values of feed intake.

The inclusion of HWM in the diets was shown to have no significant effects on the feed-gain ratio of the piglets fed different dietary inclusion levels of HWM. This was in accordance with the work of Vanderpopuliere, et al., (1976) who reported in layers that egg production, feed conversion, egg shell and interior quality at 8 and $16 \%$ inclusion levels of HWM were comparable to or better than the control diets. Dhaliwal, et al., (1998) also reported that both the body weight gains and feed conversion ratio revealed no statistically significant difference among different treatment groups when HWM replaced fishmeal at 0, 33.3, 66.6 and $100 \%$ levels in broiler rations.

The seemed increase in feed-gain ratio observed as the levels of HWM in the diets increased is as a result of decrease in body weight gain, which had earlier been associated with feed intake. Kempster (1945) and Wisman (1964) observed that feed conversion efficiency was inferior when HWM was used to feed broiler chicks, probably because of high ash content.

The reduction in feed cost with the higher inclusion levels of HWM in piglets diets implies that HWM as a feedstuff has the potential of saving cost of feed thereby increasing profit margin to the farmer.

The significant difference in nitrogen retained by the piglets fed graded levels of HWM was probably due to the significant difference in nitrogen intake since there was no significant difference in nitrogen output. 
The nitrogen intake was obviously influenced by feed intake. This was in agreement with the conclusion of Belewu and Ologunleko (1996) that HWM may influence conditions such as consumption and digestibility

of crude protein. This indicates that the piglets fed on the control diet better utilized the nitrogen content of the diets.

Based on the results of feed to gain ratio and feed cost per Kg of weight gain, early weaned piglets can tolerate up to $22.5 \% \mathrm{HWM}$ in their feed. Inclusion of HWM in feed will reduce the cost of feed since the HWM is an unconventional protein feedstuff. The waste is readily available, with most hatcheries in Nigeria hatching twice per week and the waste constituting disposal problems.

\section{References}

A.O.A.C (1985). Association of Official and Analytical chemists. Official Methods of Analysis, $15^{\text {th }}$ Edition. Washington DC.

Belewu, M.A. (1986). The Effect of Hatchery By-product Meal in Calcium Deficiency of Guinea Fowl Layer Ration. M.Sc. Thesis. Department of Animal Science. University of Ibadan. Ibadan. Unpublished.

Belewu, M.A; Ologunleko, A.A. (1996). Digestibility and Nitrogen utilization Hatchery by-product as a Source of Protein for West African Dwarf Goats. Nigerian Journal of Pure and Applied Sciences. 11:392-393.

Carpenter, K.J.D; Clegg, K.M. (1956). The Metabolizable Energy of Poultry $\quad$ Feeding Stuff in relation to their Chemical Composition. Journal of Science Food and Agriculture. 7:45-48.

Church, D.D. (1973). Digestive Physiology and Nutrition of Ruminants. Volume 1.D.C.Church. Washington DC.

Dhaliwal, A.P.S; Shingari, B.K; Sapra, K.L.(1998). Feeding value of Extruded Hatchery Waste Mixture in Poultry: Performance of Commercial B roilers. Pakistan Veterinary Journal. 18(3): 116-191.

Duncan, D.B. (1955). Multiple Range and Multiple F-test. Biometric.11:1-42.

Kempster, H.L. (1945). The use of Dried Incubator Offal in chick Rations. Po u l try Science. 24: 396-398.

Olatidoye O. (2003). Effects of Feeding Hatchery Waste to Grower Pigs. B. $\quad$ A g r i c . Thesis. Department of Animal Production.University of Ilorin. Ilorin.

Sonaiya, E.B. (1987). Animal by products and their potential for commercial livestock feed production. In: Proc. Nat. Workshop on Alternative Formulations of Livestock Feeds in Nigeria. Babatunde, G. M. (Ed.), $\quad$ ARMTI Ilorin. 21-25 Nov, 1988. Economic Affairs Office, The Presidency, pp298-315.

Steel, R.D.G. and Torrie, J.H. (1980). Principles and Procedures of Statistics. A Biometrical Approach. $2^{\text {nd }}$ Edition. Page 623.

Vanderpopuliere, J.M; Kanungo, H.K. and Walton, H. V.(1976). Broiler and Egg-type Chick Hatchery By-product Meal Evaluated as Laying Hen Feedstuff. Poultry Science. 56: 1140-1144. 
Adeniji and Adesiyan

Table 1: Composition of the Experimental Diets $(\mathrm{kg} / 100 \mathrm{~kg})$.

\begin{tabular}{llllll}
\hline Ingredients & $\mathbf{1}$ & $\mathbf{2}$ & $\mathbf{3}$ & $\mathbf{4}$ & $\mathbf{5}$ \\
\hline Hatchery waste meal & 0.00 & 7.50 & 15.00 & 22.50 & 30.00 \\
Maize & 30.00 & 30.00 & 30.00 & 30.00 & 30.00 \\
Soya bean meal & 30.00 & 22.50 & 15.00 & 7.50 & 0.00 \\
Palm kernel cake & 7.50 & 7.50 & 7.50 & 7.50 & 7.50 \\
Wheat offal & 8.00 & 8.00 & 8.00 & 8.00 & 8.00 \\
Corn bran & 16.50 & 15.50 & 13.00 & 10.00 & 8.00 \\
Fish meal & 4.00 & 4.50 & 4.50 & 4.50 & 4.50 \\
Blood meal & 0.00 & 0.50 & 3.00 & 6.00 & 8.00 \\
Bone meal & 2.50 & 2.50 & 2.50 & 2.50 & 2.50 \\
Oyster shell & 1.00 & 1.00 & 1.00 & 1.00 & 1.00 \\
*Premix & 0.25 & 0.25 & 0.25 & 0.25 & 0.25 \\
Salt & 0.25 & 0.25 & 0.25 & 0.25 & 0.25 \\
\hline Total & $\mathbf{1 0 0 . 0 0}$ & $\mathbf{1 0 0 . 0 0}$ & $\mathbf{1 0 0 . 0 0}$ & $\mathbf{1 0 0 . 0 0}$ & $\mathbf{1 0 0 . 0 0}$ \\
\hline
\end{tabular}

Proximate Composition (analyzed values)

$\begin{array}{lcclcc}\text { Dry matter (\%) } & 82.16 & 83.16 & 89.04 & 83.32 & 87.04 \\ \text { Crude protein (\%) } 16.23 & 16.90 & 17.62 & 15.78 & 16.88 \\ \text { Ether extract(\%) } & 1.80 & 2.40 & 2.20 & 0.50 & 0.70 \\ \text { Crude fibre (\%) } & 6.80 & 7.70 & 5.80 & 2.40 & 3.00 \\ \text { Ash }(\%) & 9.00 & 8.00 & 12.00 & 11.00 & 16.00 \\ \text { NFE (\%) } & 48.33 & 48.08 & 51.42 & 53.64 & 50.46 \\ \text { Met. energy (kcal/kg) } & 2360.98 & 2222.16 & 2067.89 & 1914.14 & 1760.39\end{array}$

*Premix used contained: Vit. A, 10000000IU; Vit. D3, 2000000 IU; Vit. E, 20000mg; Vit.K, 2000mg; Vit.B1, 3000mg; VitB2, 5000mg; VitB6, 4000mg; Vit.B12, 20mg;Niacin, 45000mg; Calcium pantothenate, 10000mg; Choline Chloride, 300000mg; Folic acid, 1000mg; biotin, 50mg; manganese, 300000mg; iron, 120000mg; Zinc, $80000 \mathrm{mg}$; copper, 8500mg; iodine, $1500 \mathrm{mg}$; cobalt, $300 \mathrm{mg}$; selenium, $120 \mathrm{mg}$; and antioxidant, $120000 \mathrm{mg}$

Table 2: Performance of Earlv-Weaned Piglets Fed on the Different Levels of HWM

\begin{tabular}{lllllll}
\hline Parameters & \multicolumn{5}{c}{ Levels of $H W M$} \\
\cline { 2 - 7 } & $0 \%$ & $7.5 \%$ & $15 \%$ & $22.5 \%$ & $30 \%$ & \pm SEM \\
\hline Initial body weight $(\mathrm{Kg})$ & 3.90 & 3.63 & 3.85 & 3.85 & 3.85 & $0.33 \mathrm{NS}$ \\
Final body weight $(\mathrm{Kg})$ & $18.46^{\mathrm{a}}$ & $9.79^{\mathrm{b}}$ & $7.77^{\mathrm{bc}}$ & $6.09^{\mathrm{cd}}$ & $4.97^{\mathrm{d}}$ & 0.39 \\
Feed intake $(\mathrm{Kg} /$ day) & $0.57^{\mathrm{a}}$ & $0.27^{\mathrm{b}}$ & $0.23^{\mathrm{b}}$ & $0.13^{\mathrm{b}}$ & $0.13^{\mathrm{b}}$ & 0.05 \\
Body weight gain $(\mathrm{Kg} /$ day) & $0.26^{\mathrm{a}}$ & $0.11^{\mathrm{b}}$ & $0.07^{\mathrm{c}}$ & $0.04^{\text {cd }}$ & $0.02^{\mathrm{d}}$ & 0.007 \\
Feed-gain ratio & 2.19 & 2.45 & 3.29 & 3.25 & 6.50 & $4.43 \mathrm{NS}$ \\
*Feed cost $(\mathrm{N} / \mathrm{Kg})$ & 43.87 & 41.96 & & 38.93 & 35.92 & 32.88 \\
Feed cost/weight gain $(\mathrm{N} / \mathrm{Kg}) 96.08$ & 102.80 & & 128.08 & 116.74 & 213.72 & $73.13 \mathrm{NS}$ \\
\hline
\end{tabular}


Adeniji and Adesiyan

a,b,c,d. Means in the same row with different superscription are significantly different $(\mathrm{p}<0.05)$ NS: Not significant; S.E.M. Standard error of mean

*Determined based on market price at the time experiment was conducted. $(\mathrm{N} 136=\$ 1)$.

Table 3: Effects of HWM onNitrogen Digestibilityof Piglets

\begin{tabular}{lcccccc}
\hline Parameters & \multicolumn{7}{c}{ Levels of HWM } \\
\cline { 2 - 7 } & $0 \%$ & $7.5 \%$ & $15 \%$ & $22.5 \%$ & $30 \%$ & \pm SEM \\
& & & & & & \\
\hline Nitrogen intake (g/day) & $18.20^{\mathrm{a}}$ & $16.20^{\mathrm{b}}$ & $10.43^{\mathrm{c}}$ & $4.55^{\mathrm{e}}$ & $6.21^{\mathrm{d}}$ & 0.10 \\
Urinary nitrogen (g/day) & $0.29^{\mathrm{a}}$ & $0.29^{\mathrm{a}}$ & $0.24^{\mathrm{b}}$ & $0.13^{\mathrm{c}}$ & $0.16^{\mathrm{c}}$ & 0.02 \\
Faecal nitrogen (g/day) & $2.89^{\mathrm{e}}$ & $3.41^{\mathrm{a}}$ & $3.20^{\mathrm{c}}$ & $2.97^{\mathrm{d}}$ & $3.26^{\mathrm{b}}$ & $5 \times 10^{-5}$ \\
Nitrogen output (g/day) & 3.18 & 3.70 & 3.44 & 3.10 & 3.42 & $\mathrm{NS}$ \\
Nitrogen retained(g/day) & $15.02^{\mathrm{a}}$ & $12.50^{\mathrm{b}}$ & $6.99^{\mathrm{c}}$ & $1.45^{\mathrm{e}}$ & $2.79^{\mathrm{d}}$ & 0.34 \\
Nitrogen digestibility (\%) & $82.53^{\mathrm{a}}$ & $77.16^{\mathrm{b}}$ & $67.02^{\mathrm{c}}$ & $31.87^{\mathrm{e}}$ & $44.93^{\mathrm{d}}$ & 0.44 \\
\hline
\end{tabular}

a,b,c,d,e: Means in the same row with different superscription are significantly different $(\mathrm{p}<0.05)$ NS: Not significant; S.E.M: Standard error of mean. 
Agrosearch (2007) 9 No 1\&2: 23 - 32

\section{COMPARATIVE PRODUCTIVITY BETWEEN FARMER COOPERATOR AND NON-COOPERATOR FARMERS IN KWARA STATE. NIGERIA. Fakayode, S.B*and Orebiyi, J.S+ \\ *Department of Agricultural Economics and Farm Management. University of Ilorin, Ilorin.Nigeria. e-mail segun fakayode@yahoo.com \\ +Department of Agricultural Economics, F.U.T, Owerri., Nigeria}

\section{Abstract}

This study examined the role of cooperatives in agricultural productivity in Kwara state, Nigeria. Ninety (90) farmer cooperators and ninety (90) non-cooperator farmer households were randomly sampled across the state. The study data were analysed using the Total Factor Productivity (TFP) and the Ordinary Least Squares (OLS) regression methods. Study findings showed that TFP averages were very low 4.40 and 3.60 for farmer cooperators and noncooperators farmer households respectively. Major determinants of farm productivity for the two household groups were land (farm size), labour, educational status of household head and household size while partial productivity for farmer cooperator averaged 1.11 and 0.764 for land and labour respectively. Partial productivity for non-cooperator farmer were 0.967 and 0.618 for land and labour respectively. This study therefore, recommends that farmer participation in viable cooperative be encouraged so as to expand farm production per hectare. Land and labour saving technologies review was also suggested.

Key words; Cooperator, Non-cooperator, Productivity

\section{Introduction}

The crucial issue in the Nigerian agriculture is that of low and declining crop productivity. The Nigerian farming households are poor with little access to productive resources such as land and inputs for attaining physical efficiency in food production. This in turn could lead to food insecurity and insufficient income to purchase the needed calorie food. The Nigerian farmers are poor not because of their small scale size operations, but because their farming systems are characterized by low and declining productivity (Ajibefun and Abudulkadir, 2004). Despite all human and material resources devoted to agriculture, the productive efficiency for most crops still fall under 60 percent (FACU, 1992; FDA, 1993, 1995) Farmers output can therefore be expanded with existing levels of conventional inputs and technology.

The efficiency with which farmers uses existing resources and technology is crucial in agricultural production. This is more so where farmers are not making efficient use of existing technology in the face of geometrical growth in population, increasing pressure on natural endowed resources, diminishing traditional fallows and fast shrinking land frontiers. More than ever farmers will have to produce more efficiently for maximum output from a given mix of inputs or use the minimum level of inputs for a given level of output. It is thus of policy relevance to seek ways of achieving substantial gains in agricultural productivity. It is the view of most writers that an effective economic development strategy depends critically on promoting productivity and output growth in the agricultural sector, particularly among small scale producers (Bravo-Ureta and Pinhero, 1997). Along this line scholars have long advocated for the cooperative option as a way to remedying the declining productivity of the farm sector in Nigeria. 
According to Igben (1985) cooperatives which served the agricultural sector were organised to improve production levels and provide a more efficient marketing system through the use of an increasing efficiency of biological, chemical and mechanical technology. The establishment and growth of cooperative societies in Nigeria stemmed from the believe that rural cooperation like that found in agricultural cooperatives will help mobilize resources so that farmers can obtain credit for production and marketing. Farmer cooperators like other cooperator are usually obligated to deposit an agreed sum of money with societies at agreed times. From these savings deposited, farmers can mobilize substantial credit. This will in turn protect them from untimely and uneconomic sales of their crops and livestock (Omotesho, 1994; Orebiyi and Fakayode 2005).

This study therefore examined the role of farmer cooperative membership on the productivity of farms, using Kwara State as a case study. The specific objectives of the study were to estimate and compare productivity levels on farmer cooperator and non-cooperator farmer farms and identify the determinants of agricultural productivity for the farmer cooperator and non-cooperator farmer household farms.

\section{Methodology and Data Collection}

The study was conducted in Kwara State, Nigeria. Kwara State lies between latitudes $7^{0}$ $45^{\prime} \mathrm{N}$ and $9^{\circ} 30^{\prime} \mathrm{N}$ and longitudes $2^{\circ} 30^{\prime} \mathrm{E}$ and $6^{\circ} 25^{\prime} \mathrm{E}$. The State covers a total land area of about 332,500 square kilometers and shares boundary with Ondo, Oyo, Osun, Niger and Kogi States in Nigeria and an international border with the Republic of Benin along its north-western part (Kwara State Ministry of Information, 2002). The State has a population of about 2.37million people (NPC,2006).

The study sample design was based on Kwara State Agricultural Development Project (KWADP) Authority zoning of kwara state's sixteen Local Government Areas into 4 zones in consonance with ecological characteristics and cultural practices and the sampling frame of cooperatives in Kwara state. The sample frame for the cooperative societies across the state was obtained from the Kwara State Ministry of Commerce, Industry and Cooperatives. The cooperative frame was used to determine the number, spread and type of cooperative societies in the state, as well as their classification into rural/urban types. Almost all the cooperative societies were found to be the multi-purpose types.

Based on the foregoing albeit pertinent information, the sampling technique for the study comprised a three stage sampling procedure. The first stage comprised the random selection of fifteen villages/rural localities across Kwara State, while the second stage involved the random selection of two cooperative societies each from the village/rural locality selected. The choice of village/rural cooperatives for the study was premised on the fact that farmers' cooperatives in Nigeria are rural rather than urban (Ihimodu 1988). Cooperative members in these rural areas are mostly farmers (Fakayode, 2005). The last sampling stage involved the random selection of 3 farmer cooperator households from each cooperative society selected. Also 6 noncooperator farmer households were randomly selected from each village/rural locality selected. The sample for the study therefore comprised 90 farmer cooperator households and 90 noncooperator farmer household respondents. All these respondents were interviewed for the study (Table1). 
Fakayode and Orebiyi

$\mathrm{TFP}=\frac{\mathrm{Y}}{\mathrm{TVC}}$

$$
\mathrm{TFP}=\frac{\mathrm{Y}}{\Sigma \mathrm{PiXi}}
$$

But $\mathrm{AVC}=\frac{\mathrm{TVC}}{\mathrm{Y}}$

Therefore $\mathrm{TFP}=\frac{\mathrm{Y}}{\mathrm{TVC}}=\frac{1}{\mathrm{AVC}}$

\section{Partial Productivity}

Following Piana (2001), the factor (partial) or average productivity (PF)

$\mathrm{PFi}=\mathrm{Y} / \mathrm{X}$

where PFi is the average product or partial productivity of the ith input, $\mathrm{Y}$ and $\mathrm{X}$ are the mean values of the crop output and input of farmer household respectively.

\section{Regression Analysis}

Following Key and Mebride, (2003) to examine the influence of socio-economic variables or determinants of productivity on TFP, the estimating equations is specified as in equation (4)

$\mathrm{TFP}=\mathrm{b}_{\mathrm{o}}+\Sigma \mathrm{b}_{\mathrm{i}} \mathrm{X}_{\mathrm{i}}+\mathrm{e}_{\mathrm{i}}$

All the factors hypothesized as determinants of farm productivity were therefore fitted into the regression equation (4) for the cooperator and non-cooperator farmers respectively. TFP $=$ Total Factor Productivity, Xi s are the hypothesized determinants of farm productivity. These include land (farm size) $\left(\mathrm{X}_{1}\right)$, labour $\left(\mathrm{X}_{2}\right)$. educational status of household head $\left(\mathrm{X}_{3}\right)$ and standardized household size $\left(\mathrm{X}_{4}\right)$ (Hussein and Perera, 2005).

\section{Chow Test}

The chow test (Chow, 1961) is a predictive test for stability. Wilson (1978) argues that though the chow test has been suggested only for the case of $n_{2}<(k+1)$ that is for the case when the analysis of variance test can not be used. The test has desirable power properties where there are some unknown specification errors. Hence it should be used where the analysis of variance test can be computed.

Suppose that we have two independent sets of data with simple sizes $n_{1}$ and $n_{2}$ respectively. The regression equations are

$Y=a_{1}+B_{11} X_{1}+B_{12} X_{2}+\ldots B_{1 K} X_{K}+$ Ù for first set

$\mathrm{Y}=\mathrm{a}_{2}+\mathrm{B}_{21} \mathrm{X}_{1}+\mathrm{B}_{22} \mathrm{X}_{2}+\ldots \mathrm{B}_{2 \mathrm{~K}} \mathrm{X}_{\mathrm{K}}+$ Ư for second set 
For the Bs the first subscript denotes the data set and the second subscript denotes the variable. A test for stability of the parameters between the populations that generated the two data sets is a test of the hypothesis

Ho: $\mathrm{B}_{11}=\mathrm{B}_{21}, \mathrm{~B}_{12}=\mathrm{B}_{22}, \ldots, \mathrm{B}_{1 \mathrm{~K}}=\mathrm{B}_{2 \mathrm{~K}}$ and $\boldsymbol{\alpha}_{1}=\mathbf{\alpha}$

Simply put, the chow test is used to test whether our regressions (in this case 5 and 6), have equal intercepts or slopes or both. i.e whether the dependent variable $\mathrm{Y}$ in the different conditions implied by the two regression equations are equal and or the influences of the independent, explanatory variables $\mathrm{X}_{\mathrm{i}} \mathrm{s}$ are equal on the dependent variable $\mathrm{Y}$ in the two conditions implied by the two regression equations for independent sample sets $n_{1}$ and $n_{2}$ respectively.

For this study, the chow test was therefore employed to test if the influences of the factors hypothesized as determinants of productivity were the same on farm productivity, for the farmer cooperator and non-cooperator farmer respectively. The chow test hypothesis for the study is stated as

$\mathrm{H}_{\mathrm{o}}: \mathrm{B}_{\mathrm{c} 1}=\mathrm{B}_{\mathrm{nc} 1}, \mathrm{~B}_{\mathrm{c} 2}=\mathrm{B}_{\mathrm{nc} 2}, \ldots, \mathrm{B}_{\mathrm{nk}}=\mathrm{B}_{\mathrm{nck}}$ and $\boldsymbol{\alpha}_{\mathrm{c}}=\boldsymbol{\alpha}_{\mathrm{c}}$

Where $\mathrm{B}_{\mathrm{ci}}$ and $\mathrm{B}_{\mathrm{nc1}}$ are the parameters for the ith determinant in the cooperator and noncooperator farmer regressions respectively, while $\boldsymbol{\alpha}_{\mathrm{c}}$ and $\boldsymbol{\alpha}_{\mathrm{nc}}$. are the.intercept terms for the cooperator and non-cooperator farmer regressions respectively.

The test involves estimating an F-ratio from our OLS equations (4) as in equation (9)

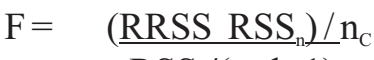

Which has an F-distribution with degrees of freedom $n_{C}$ and $n_{n} k-1$. where

$\mathrm{n}_{\mathrm{C}}=$ sample size of farmer cooperators households

$\mathrm{n}_{\mathrm{n}}=$ sample size of non-cooperators.farmer households

RRSS $=$ Residual sum of squares from the regression based on $n_{C}+n_{n}$ observations; this has degree of freedom $\left(\mathrm{n}_{\mathrm{C}}\right.$ and $\left.\mathrm{n}_{\mathrm{n}} \mathrm{k}-1\right)$.

$\mathrm{RSSc}=$ Residual sum of squares from the regression based on $\mathrm{n}_{\mathrm{C}}$ observations, this has degree of freedom $\left(\mathrm{n}_{1} \mathrm{~K}-1\right)$

The decision rule is to accept our null hypothesis, if calculated $\mathrm{F}<\mathrm{F}$ table and reject null hypothesis if otherwise.

\section{Results and Discussion}

\section{Productivity Estimation; TFP Estimates}

From data analysis, the TFP estimates was found to range between 2.40-6.90 and 2.306.30 for the farmer cooperator and non-cooperator farmer farms respectively. On an average basis, the TFP was 4.40 and 3.60 for the farmer cooperator and non-cooperator farmer respectively (Table 2). Also the differences in TFP averages between the farmer cooperator and farmer non-cooperator household is small (0.8) considering the numerous advantages that can accrue to the farmer when he is a member of a cooperative society. 


\section{Factor Productivity Estimates}

The partial productivity indices for the variables land (farm size) $\left(\mathrm{X}_{1}\right)$, labour $\left(\mathrm{X}_{2}\right)$. educational status of household head $\left(\mathrm{X}_{3}\right)$ and standardized household size $\left(\mathrm{X}_{4}\right)$ were greater for the farmer cooperator than for the non-cooperator farmer. For the farmer cooperator, the factor productivities averaged 1.11 for land, 0.76 for labour 1.42 for educational status of household head and 0.886 for household size. For the non-cooperator farmer, the factor productivity indices averaged 1.0 for land, 0.62 for labour, 1.33 for educational status of household head and 0.89 for household size (Table 3 ). From the result the productivity for land and labour across the two farmer groups seem very low for any meaningful large scale farm production. This is more so since the partial productivity indices for these two variables for the farmer cooperator are small with only 0.11 and 0.14 respectively over those for the non-cooperator farmer. This result is so probably because farmers in cooperative societies (farmer cooperators) have not availed themselves sufficiently of cooperative benefits.

\section{Determinants of farm Productivity; OLS Estimates}

From the regression estimates the lead equations selected are the linear equation for the farmer cooperator household farm and the semi-log for the non-cooperator farmer household farm. The estimated equations are presented as equations (10) and (11)

$$
\begin{aligned}
& \text { For Farmer Cooperator. } \\
& \mathrm{Y}=182.532+17.967 \mathrm{X}_{1}+0.0788 \mathrm{X}_{2}+0.07218 \mathrm{X}_{3} \quad 0.0350 \mathrm{X}_{4} \\
& \begin{array}{lllll}
37.459 & 3.139 & 63.7944 & 37.129 & 0.0146
\end{array} \\
& \begin{array}{lllll}
(4.873) & (5.724)^{*} & (5.027)^{*} & (2.68)^{*} & (2.3972)^{*}
\end{array} \\
& \mathrm{R}^{2}=0.778 \\
& \mathrm{~F}=1236.516^{*} \\
& \text { For Non-cooperator Farmer } \\
& \mathrm{Y}=\log 0.275+0.244 \log \mathrm{X}_{1}+0.177 \log \mathrm{X}_{2}+0.922 \log \mathrm{X}_{3}+0.737 \log \mathrm{X}_{4} \\
& \begin{array}{lllll}
0.043 & 0.041 & 0.026 & 0.388 & 0.371
\end{array} \\
& (6.356) \quad(5.927)^{*}(6.716)^{*} \quad(2.375) *(1.985)^{*} \\
& \mathrm{R}^{2}=0.745 \\
& \mathrm{~F}=14.382 * \text {. }
\end{aligned}
$$

The result of the lead linear function for the farmer cooperator household equation (1) showed that land $\left(\mathrm{X}_{1}\right)$, labour $\left(\mathrm{X}_{2}\right)$, education status of household head $\left(\mathrm{X}_{3}\right)$ and household size $\left(\mathrm{X}_{4}\right)$ were significant at 1 per cent level. These variables therefore showed significant influences on the productivity of the farmer cooperator farms. These variables were therefore identified as the determinants of farm productivity for the farmer cooperator farmer. The land, labour, and education status of household head variables' co-efficients have the expected positive signs. These variables therefore conform to expectations. The variables positive co-efficients implies that the variables contribute to the farmer cooperators' farm productivity. The household size variable co-efficient also had the expected sign, negative. It therefore also conforms to apriori expectations. The negative co-efficient implies that the larger the household, the lower the farmer cooperators' farm productivity. The negative household size influence might be because the farmers' little earnings from their farms, other income sources are not usually invested into agriculture, instead the household incomes is usually expended on consumption expenses like 
settling children school fees and meeting other domestic needs. This is more so as the households becomes larger, especially nowadays where most of the able bodied persons in the household do not partake in farming. The co-efficient of determination $\mathrm{R}^{2}$ value was 0.778 for the farmer cooperator indicating that about 77.8 per cent of the variability in the farm productivity for the farmer cooperator is accounted for by the variables included in the farmer cooperator regression. The F-ratio is $1236.516^{*}$ and significant at 1 per cent level indicating that the joint effects of all the included variables were significant for the farmer cooperator farm productivity.

For the non-cooperator farmer, the result of lead semi-log equation (2) showed that land $\mathrm{X}_{1}$, labour $\left(\mathrm{X}_{2}\right)$, education status of household head $\left(\mathrm{X}_{3}\right)$ and household size $\left(\mathrm{X}_{4}\right)$ were significant at 1 per cent level. These variables therefore showed significant influences on the productivity of the non-cooperator farmer farms. These variables were therefore identified as the determinants of farm productivity for the non-cooperator farmer farms. The land, labour, and education status of household head variables' co-efficients also have the expected positive signs. The variables therefore conform to expectations. The variables positive co-efficients implies that the variables contribute to the farmer cooperators' farm productivity. The household size variable co-efficient also had the expected sign, negative and therefore conforms to apriori expectations. The negative co-efficient implies that the larger, the household the lower the non-cooperator farmer farm productivity. The increasing family consumption expenditure as the household becomes larger, might also be responsible for the negative sign of the household size variable co-efficient in the non-cooperator farmer case as is the case for the cooperator farmer. The co-efficient of determination $\mathrm{R}^{2}$ value was 0.745 for the non-cooperator farmer, indicating that about 74.5 per cent of the variability in farm productivity for the non-cooperator farmer is accounted for by the variables included in the non-cooperator farmer regression. The F-ratio is 14.382 and significant at 1 per cent level indicating that the joint effects of all the included variables were significant for the non-cooperator farmer farm productivity.

Generally the result of the estimates for the variables hypothesized as determinants of productivity showed that land, labour, education status of household head and household size are determinants of farm productivity for both the farmer cooperator and non-cooperator farmer farms. This finding agrees with Hussein and Perera (2005) who emphasized the influences of these four variables on farm productivity. However, only the

influences of three of these factors, land, labour, and education status of household head, on crop productivity were indicated in the study by Ogundari and Ojo (2007). In their assessment of factors affecting small-scale farm productivity in Nigeria, positive co-efficients were obtained for the three variables thereby establishing their contributions to farm productivity. The influence of household size on farm productivity was not indicated. In his own study Rahji (2005) established the influence of land, education status of household head and household size on the productivity of lowland rice farms in Niger state, Nigeria. Another study conducted by Okoruwa and Ogundele (2005) indicated the influence of land and household size on rice productivity. Land was found to significantly contribute to farm productivity.

\section{Chow test Result.}

The chow test result indicated significant differences between the same variable coefficients included in the farmer cooperator and farmer non-cooperator household regressions (Table 4). The calculated F is 1.824 and it is greater than the table $\mathrm{F}$ value at $5 \%$ level. This 
implies that the influences of the variables hypothesized as the determinants of productivity on farm productivity, significantly differ between the farmer cooperator and non-cooperator farmer household farms. The influence of cooperatives on household farm productivity is therefore established.

\section{Conclusion and Recommendations}

The popular opinion that the cooperative is an important tool to mobilizing the resources of peasants to improve their farm production has been shown to be true in this study. Farm productivity levels are higher when farmers join or form cooperatives. The study finding showed that farm productivity for the farmer cooperator was at a TFP level of 4.40 and higher than that for the non-cooperator farmer, with a TFP level of 3.60. Partial productivity for land, labour, educational status of the farmer and the household size of the farmers were also found to be higher for the farmer cooperator household. However, the productivity of the farmer cooperator farms were found to be low. The factors identified as determinants of productivity were the land (farmsize), labour, educational status of the farmer and the household size of the farmer. Land, labour, and the educational status of the farmer were shown to be contributory to the farmers farm productivity while the household size limited farm productivity.

Based on the findings of this study therefore, the study recommends the need to raise farm productivity in the study area. In this respect farmers should be encouraged to improve upon their farm knowledge and practices. There is an urgent need to ensure easy access of farmers to adult and farm-related education. When farmers are educated, they can better appreciate improved technologies and even use them appropriately. This would in turn improve the productivity of farm resources. Efforts at mobilizing farmers into viable cooperative groups should also be pursued vigorously. This will help mobilize rural savings that can be made readily available to the farmers. Assess to more land and labour can no doubt improve farm productivity, but acquisition of additional quantities of both resources can be quite impossible in the short to medium term periods. As such, novel land management and labour-saving technologies and farm practices should be extended to farmers in the study area.

\section{References}

Alene, D.A. and Hassan, M.R. (2003): "Total Factor Productivity and Resources use Efficiency of Alternative Cropping Systems in Two Agro- Climatic Zones in Eastern Ethopia.".Agricultural Economic Review 4(2).

Ajibefun A.I and Abdulkadir, A.O. (2004): "Impact of Size of Farm Operation on Resource Use Efficiency in Small-scale Farming". Evidence from Southwestern Nigeria. Journal of Food Agriculture and Environment. 2 (1):359-364.

Bravo-Ureta, B.E. and Pinheiro, A.E: (1993): " Efficiency Analysis of Developing Country Agricultural: A Review of the Frontier Function Literature". Agricultural and Resources Economics Review 22 (1):88-101.

SubseChow,G.C(1961) "Test of Equality Between t of Co-efficients in Two Linear Regression Models. Econometrica 591-605

FACU (1992): Proceedings on the $4^{\text {th }}$ Annual National Farming Systems. Research and Extension Workshop. Federal Agricultural Coordinating Unit (FACU) Reports, Ibadan. 
Fakayode and Orebiyi

Fakayode, S.B (2005):"Savings Mobilisation by Cooperatives in Kwara State".An Unpublished M.Sc Thesis Submitted to the Department of Agricultural Economics and Farm Management. University of Ilorin. Ilorin.

FDA (1993). Federal Department of Agriculture: "Food Security and Nigerian Agriculture,Water Resources and Rural Development.".Federal Department of Agriculture Bulletin Abuja, Nigeria

FDA (1995.): Federal Department of Agriculture; Federal Ministry of Agriculture Reports, Abuja, Nigeria.

Hussein, I and Perera, I.R (2005): "Improving Agricultural Productivity through Integrated Service Provision with Public-Private Sector Partnership" . Working Paper 66. Columbia. Sri Lanka: International Water Management Institute.

Igben, M.S (1985):"Financial Structure of Agricultural Cooperative Produce Marketing Societies in Oyo State in Nigeria". Nigerian Journal of Rural Development and Cooperative Studies 1(2)

Ihimodu,I.I(1988); 'Cooperative Economics; A Concise Analysis in Theory and Applications. Unilorin Press.Nigeria.15-40

Key,N and Mcbride,W (2003): 'Production Contracts and Productivity in the US Hog Sector". American Journal of Agricultural Economics 85(1)121-133

Kwara State Ministry of Information (2002) "Kwara State Diary 2002."110.National Population Commission (NPC) (2006): "Population of Kwara State" National Population Commission of Nigeria. Abuja (2006).

Ogundari, K and Ojo,S.O (2007): "Economic Efficiency of Small Scale Food Crop Production in Nigeria: A Stochastic Frontier Approach. Journal of Social Science 14(2).

Okoruwa, V.O and Ogundele, O.O (2005) "Technical Efficiency Differentials in Rice Production Technologies in Nigeria". Nigerian Institute for Social and E c o n o m i c Research (NISER) Ibadan Nigeria

Omotesho O .A (1994) "Cooperative as a Vehicle for Mobilizing Resource Poor Farmers in Nigeria".Journal of Rural Development and Administration. .Pakistan Academy for Rural Development and Administration. Peshawar XXVI: (2):15-20

Orebiyi J.S and Fakayode,S.B (2005); "Determinants of Savings Mobilisation by Farmer Cooperators in kwara State, Nigeria. International Journal Agriculture and Rural Development. .School of Agriculture and Agricultural Technology. Federal University of Technology .Owerri (6);66-73

Piana, V (2001):"Productivity" Economics Web Institutes. Accessed at http://www.economicswebinstitute.org/mainhtm.retrieved $22 / 06 / 2006$.

Rahman, S. A (2003): "Agricultural Biotechnology: A Prospect for Food Security in Africa". Paper Presented at the $37^{\text {th }}$ Annual Conference of the Agricultural Society of Nigeria (ASN)held at the University of Calabar 16-20 November, 2003

Wilson,A.L(1978): "When is the Chow Test Ump? .The American Statistician. 32(2) 66-68 
Fakayode and Orebiyi

Table 1: Summary of Study Sample Design .

\begin{tabular}{|c|c|c|c|}
\hline $\begin{array}{l}\text { Village/Rural } \\
\text { Locality }\end{array}$ & $\begin{array}{l}\text { No of cooperative } \\
\text { societies }\end{array}$ & $\begin{array}{l}\text { No of farmer cooperator } \\
\text { household at 3 per } \\
\text { cooperative society }\end{array}$ & $\begin{array}{l}\text { No of Non-cooperator } \\
\text { farmer household at 6 per } \\
\text { village. }\end{array}$ \\
\hline Lafiagi & 2 & 6 & 6 \\
Tsaragi & 2 & 6 & 6 \\
Tsongi & 2 & 6 & 6 \\
Osi & 2 & 6 & 6 \\
Idofin-Igbana & 2 & 6 & 6 \\
Idofin & 2 & 6 & 6 \\
Rore & 2 & 6 & 6 \\
Ipetu & 2 & 6 & 6 \\
Eleyin & 2 & 6 & 6 \\
Pategi & 2 & 6 & 6 \\
Lade & 2 & 6 & 6 \\
Kpada & 2 & 6 & 6 \\
Oloru & 2 & 6 & 6 \\
Paiye & 2 & 6 & 6 \\
Malete & 2 & 6 & $\mathbf{9 0}$ \\
\hline Total & $\mathbf{3 0}$ & $\mathbf{9 0}$ & 6 \\
\hline
\end{tabular}

Source: Field Survey, July 2003.

Table 2: Frequency Distribution of Household Farm Total Factor Productivity TFP Estimates.

\begin{tabular}{|c|c|c|c|c|}
\hline \multirow[t]{2}{*}{ TFP Indice } & \multicolumn{2}{|c|}{ Farmer Cooperator } & \multicolumn{2}{|c|}{ Non-cooperator Farmer } \\
\hline & Frequency & Percentage \% & Frequency & Percentage $\%$ \\
\hline $2.1-3.0$ & 19 & 20.1 & 26 & 28.4 \\
\hline $3.1-4.0$ & 16 & 17.5 & 50 & 55.7 \\
\hline $4.1-5.0$ & 40 & 45.5 & 9 & 10.2 \\
\hline $5.1-6.0$ & 13 & 14.6 & 3 & 3.6 \\
\hline $6.1-7.0$ & 2.0 & 2.3 & 2 & 2.1 \\
\hline Total & 90 & 100.0 & 90 & 100.0 \\
\hline Mean & \multicolumn{2}{|c|}{4.41} & \multicolumn{2}{|c|}{3.60} \\
\hline Standard Deviation & \multicolumn{2}{|c|}{1.26} & \multicolumn{2}{|c|}{1.33} \\
\hline Minimum & \multicolumn{2}{|c|}{2.40} & \multicolumn{2}{|c|}{2.30} \\
\hline Maximum & \multicolumn{2}{|c|}{6.90} & \multicolumn{2}{|c|}{6.30} \\
\hline
\end{tabular}

Source: Data Analysis (2005). 
Fakayode and Orebiyi

Table 3: Partial Productivity Estimates for Household Farm (Averages).

\begin{tabular}{l|c|c}
\hline & Farmer cooperator & Non-cooperator Farmer \\
\hline Land (Farm size) & 1.11 & 1.0 \\
Labour & 0.76 & 0.62 \\
Educational status & 1.42 & 1.33 \\
Standardized Household Size & 0.886 & 0.89. \\
& & \\
\hline
\end{tabular}

Source: Data Analysis (2005)

Table 4: Result of Chow-Test Comparism between Farmer Cooperator and Non-Cooperator

Farmer Households.

\begin{tabular}{l|l}
\hline RSS $_{\mathrm{c}}$ & 1.1151 \\
RSS $_{\mathrm{n}}$ & 0.0544 \\
RRSS $_{\text {Degrees of Freedom }}\left(\mathrm{n}_{\pi} \mathrm{k}-1\right)$ & 1.3966 \\
Fcal $(\mathrm{F} 90,8)$ & 85 \\
Implication & 1.824 \\
\hline
\end{tabular}

Source: Data Analysis, 2005. 